\title{
Family caregivers challenges about caring for children with impaired skin integrity ${ }^{a}$
}

\author{
Desafios dos familiares/cuidadores sobre o cuidar de crianças com perda da integridade cutânea \\ Desafíos de los familiares/cuidadores sobre cuidar de niños con pérdida de la integridad cutânea
}

Ayana Carolina Gonçalves Teixeira Matos ${ }^{1}$ (D) Evanilda Souza de Santana Carvalho ${ }^{2}$ (D) Silvia da Silva Santos Passos ${ }^{2}$ (D) Rudval Souza da Silva ${ }^{3}$ (1]

1. Hospital Estadual da Criança.

Feira de Santana, BA, Brasil.

2. Universidade Estadual de Feira de Santana.

Feira de Santana, BA, Brasil.

3. Universidade do Estado da Bahia.

Senhor do Bonfim, BA, Brasil.
Corresponding author:

Ayana Carolina Gonçalves Teixeira Matos. E-mail: ayana.teixeira@gmail.com

Submitted on $06 / 08 / 2018$.

Accepted on 10/01/2018.

DOI: 10.1590/2177-9465-EAN-2018-0173

\section{Abstract}

Objective: To know the challenges of family caregivers members for the maintenance of care for children with impaired skin integrity after hospital discharge. Method: This is a qualitative study of action research, developed from March to July of 2017. Participants were ten family/caregivers of the children with impaired skin integrity. The data obtained through interviews were submitted to content analysis. Results: The family caregivers of the child with impaired skin integrity received guidelines for home care at discharge, experienced feelings of relief, getting out of the hospital and, for fear of causing physical and emotiona damage, sought help in the services and neighborhood, overprotected the child, to avoid complications and readmission, and faced the lack of resources to care for. Conclusion: Maintenance of care for children with impaired skin integrity after hospita discharge requires application of measures of protection from skin wounds, constant surveillance of the child in order to prevent local traumas and infections, and the search for support in the Health, to obtain material resources and guidelines for care.

Keywords: Child Care; Pediatric Nursing; Caregivers; Family Health; Wounds and Injuries.

\section{Resumo}

Objetivo: Conhecer os desafios dos familiares/cuidadores para a manutenção dos cuidados à criança com perda da integridade cutânea no pós-alta hospitalar. Método: Trata-se de estudo qualitativo de pesquisa-ação, desenvolvida de março a julho de 2017. Participaram dez familiares/cuidadores de crianças com perda de integridade cutânea, no ambulatório de um hospital público pediátrico. Os dados obtidos mediante entrevistas foram submetidos à análise de conteúdo. Resultados: Os familiares/cuidadores da criança com perda de integridade cutânea recebiam orientações no momento da alta hospitalar para cuidados em domicílio, vivenciavam sentimentos de alívio, por sair da hospitalização e medo de provocar danos físicos e emocionais. Assim, buscavam ajuda nos serviços de saúde e na vizinhança, superprotegiam a criança para evitar complicações e re-hospitalização e enfrentavam a carência de recursos para cuidar. Conclusão: A manutenção dos cuidados à criança com perda da integridade cutânea no pós-alta hospitalar requer dos familiares/cuidadores aplicação de medidas de proteção das lesões cutâneas, vigilância constante da criança na prevenção de traumas locais, infecções e busca de apoio nas unidades de saúde, para obter recursos materiais e orientações para o cuidado.

Palavras-chave: Cuidado da Criança; Enfermagem Pediátrica; Cuidadores; Saúde da Família; Ferimentos e Lesões.

\section{Resumen}

Objetivo: Conocer los desafíos de los familiares/cuidadores para el mantenimiento de los cuidados al niño con pérdida de la integridad cutánea en el post alta hospitalaria. Método: Se trata de un estudio cualitativo fundamentado en los supuestos de la investigación-acción, desarrollada entre marzo hacia julio de 2017. Han Participado diez familiares/cuidadores de niños con pérdida de integridad cutánea. Los datos han sido obtenidos mediante entrevistas y sometidos al análisis de contenido. Resultados: Los familiares/cuidadores del niño con pérdida de integridad cutánea recibian orientaciones para cuidados domiciliarios en el momento de la alta hospitalaria, vivenciaban sentimientos de alivio, por salir de la hospitalización y, pero también miedo de provocar daños físicos y emocionales, buscaban ayuda de sus vecinos y de los servicios de salud, super protegían el niño para evitar complicaciones y reinternación, y enfrentaban la carencia de recursos para cuidar. Conclusión: El mantenimiento de los cuidados al niño con pérdida de la integridad cutánea en el post-alta hospitalaria requiere de los familiares/cuidadores aplicación de medidas de protección de las lesiones cutáneas, vigilancia constante del niño en la prevención de traumas locales e infecciones y búsqueda de apoyo en las unidades de atención Salud, para obtener recursos materiales y orientaciones para el cuidado.

Palabras clave: Cuidado del Niño; Enfermería Pediátrica; Cuidadores; Salud de la Família; Heridas y Lesiones. 


\section{INTRODUCTION}

Child hospitalization is a disturbing situation in the life of the child and their relatives/caregivers. ${ }^{1}$ It almost always results in changes in the family routine and presents consequences for the development of the child, which is in condition of experimentation of the world. Often justified in correcting pathological processes, however, corrective and restoration treatments and procedures secondary to home burns, surgical wound dehiscence, trauma associated with age, and conditions that have conditioned their hospitalization can cause skin wounds that will require care that extend to the post-discharge period. ${ }^{1}$

In this sense, in order to reduce costs and infectious risks arising from staying in the hospital environment, besides minimizing the physical and psychic repercussions of hospitalization on the child and his/her relatives, this permanence has been abbreviated. ${ }^{2}$ However, hospital discharge has been occurring under favorable clinical conditions, but not in total return to health. ${ }^{2}$

Considering that the process of restoring the child's health that presents with Impaired Skin Integrity (ISI) does not end with hospital discharge and, in order to ensure continuity of care, the health team needs to qualify the family caregiver throughout the process of Hospitalization to provide hospital post-discharge care. $^{3}$

Despite the advances in Pediatric Nursing, skin wounds secondary to the diagnostic, curative and restoring processes, among others, continue to be a cause of morbidity and mortality, with a magnitude of a hidden epidemic, with impacts on social and economic aspects, and with quality of life of children and their relatives/caregivers. ${ }^{4}$

The family is understood as a care unit for the child in all contexts, so it needs to be in the focus of professional care, ratifying the model of family-centered care, since the family will be responsible for the continuity of care until full recovery is achieved. ${ }^{5}$ Therefore, health professionals are required to spend time interacting with relatives/caregivers, listening to them about their fears, doubts, needs and supporting them in overcoming their limitations and difficulties. Success in child care after discharge is important so that the trauma of hospitalization is overcome and the well-being of the family can be promoted. .,6 $^{5}$

In this perspective, it is important to emphasize the importance of planned and systematized discharge from hospital, as a goal to broaden the humanization of care and strengthen strategies with the preparation of the patient, especially his family member, who will assume responsibility for the continuity of care ${ }^{6}$ Consequently, the closer communication between the hospital and the family caregiver constitutes a resolute and humanized care, as well as the strengthening of adherence to the proposed treatment and the acquisition of greater theoretical and practical ability, being essential for the reduction of relapse in the hospitalization and for the guarantee of the return to the conditions of skin integrity or of adaptation to the new reality of the child. ${ }^{6}$

In spite of this, hospital-based and family-centered activities are designed to help her cope with the hospitalization experience and often are not sufficient to prepare the child to leave the hospital. ${ }^{6}$ In addition, the family caregiver has not received guidelines that enable him/her to take care of the child with ISI, nor is he/she encouraged to participate in moments of qualification and decision making. ${ }^{6}$ The lack of planning for hospital discharge or its non-applicability during hospitalization restricts the acquisition of skills for continuity of care, since guidelines are given orally at the time of leaving the hospital, increasing anxieties, doubts and difficulties in caring for the child at home. ${ }^{4}$

The interest in this theme was based on the professional experience of one of the authors in a public pediatric hospital in Bahia State, where preparation for hospital discharge has been implanted as a care strategy. However, the Nursing appointment systematized in hospital post-discharge was not assured as a strategy of continuity of care.

Thus, after the hospitalization phase, when the relatives/ caregivers were apprehended, the following research question emerged: What challenges do relatives/caregivers find for the care of children with ISI after hospital discharge? Thus, to answer the question asked, this study aimed to know the challenges of relatives/caregivers for the maintenance of care for children with ISI after hospital discharge.

This work is relevant because it contributes to a reflection on the humanized care, with the promotion of the development of abilities and empowerment of the family caregiver in the care with quality and resolvability to the child with skin wounds in condition of hospital discharge, fact that expands the guarantee continuity of care and accessibility, reduces physical as well as emotional damage to this child and contributes to their rehabilitation and reintegration into their socio-cultural context.

\section{METHOD}

This is a qualitative study based on the presuppositions of the action research carried out in a public pediatric hospital of a Municipality in Bahia State. Action research is a social research that allows researchers to intervene in proposing solutions to the problems encountered, in the monitoring and evaluation of the actions triggered to the reach of the resolvability during the assistance, participative and modifying practices of reality. ${ }^{7-9}$

Participants were ten family caregivers of children who met the following criteria: Being over 18 years of age, being a family caregiver of children with ISI installed during hospitalization and keeping the child's follow-up in outpatient appointments in the hospital post-discharge period. There was no exclusion criteria adopted. 
In line with the action research guidelines, the nurses of the service assumed the role of social actors involved in the implantation of care for children with ISI after hospital discharge, carried out the action and, as collaborating researchers, performed nursing appointments to know the challenges of relatives/caregivers for the maintenance of child care with ISI after hospital discharge.

The relationship with the relatives/caregivers occurred in the nurses' environment during the preparation for the discharge of their child, when they were informed about the objectives, risks, benefits of the research and had a schedule for outpatient nursing appointments of their children in process of skin integrity restoration

Data were collected between March and July 2017. For this purpose, the semi-structured interview technique was used by the main researcher prior to the nursing appointments, in which the caregivers offered answers on orientations received for ensure hospital post-discharge care, feelings toward the ISI of their children, difficulties, caring skills and perceptions about the care received by the child in the post-discharge nursing appointment.

The children, together with their family caregiver, participated, on average, between six and eight nursing appointments, performed weekly in the outpatient clinic.

During the nursing appointment, the family caregiver participated by reporting their experiences, caring for the child at home, expressing doubts, offering emotional support to the child, holding her, encouraging her and minimizing tension in the accomplishment of the dressing.

The interviews were conducted in a private practice, with an average duration of $\mathbf{3 0}$ minutes. They were closed at the fourth meeting when the content saturation point was obtained and the data collection was closed with the outpatient discharge of the child after complete restoration of skin integrity.

The interviews were recorded and transcribed in their entirety and later submitted to the content analysis, proposed by Bardin, in its three phases: In the pre-analysis we proceeded to the exhaustive reading of the testimonies; then the exploration of the material consisted of identification of the nuclei of sense and categorization by similarity. Finally, we carried out the inference and interpretation on the contents seized. ${ }^{7}$

This study was approved by the Ethics Committee in Research of the Universidade Estadual de Feira de Santana, under Opinion 1,701,659 and CAAE 57534516.7.0000.0053. Participants signed the Informed Consent Term.

\section{RESULTS}

Relatives/caregivers who participated in this study were predominantly female, with an average family income ranging from 1-2 minimum wages, residing in the municipality where the research was conducted and dedicated to household activities.
The children had a contemplated age range of 1 to 13 years, most of them male and were in the process of restoring skin integrity secondary to burns at home, dehiscence of surgical wound and trauma, injuries that conditioned their hospitalization.

The results of this study were organized into four categories regarding the perceptions and challenges of relatives/caregivers regarding care of children with ISI after hospital discharge: Unprepared family caregiver for discharge during hospitalization Perceptions of family caregiver regarding hospital discharge: ambivalence of feelings; Difficulties and challenges of relatives/ caregivers to care for children with ISI; and Perceptions of the family caregiver about the post-discharge nursing appointments.

\section{Unprepared family caregiver for discharge during hospitalization}

The interaction of the relatives/caregivers with the nursing team, when effective, contributes to the learning, acquisition and modification of the behavior of those involved in the process of home care. However, discharge planning is essential in order to socialize knowledge and ensure continuity of restoration of the child's health. The lines are illustrative:

She only spoke of the care not to wet the dressing and to pass the sunflower oil three times a day ... And only at the time of discharge $(R / C 7)$.

No. She just told me to bring it here to do the dressing, and only at the time of discharge (R/C4).

She nodded and I noticed the dressing the nurse was doing. He directed me not to let the dressing have contact with animals $[. .].(R / C 5)$.

The need for rehabilitation of the child with ISI after hospital discharge leads the family to experience a set of feelings that arise when the child's sanity is interrupted and accompany it during the process of restoring skin integrity. Thus, insecurity, concern, fear, impotence and lack of preparation become constant in the lives of these relatives/caregivers when they perceive themselves deprived of preparation for discharge from the nursing team, made available in the hospital during the period of hospitalization.

\section{Perceptions of family caregiver regarding hospital discharge: ambivalence of feelings}

Concerning the perception of hospital discharge, relatives/ caregivers demonstrated experiencing antagonistic feelings.

His discharge from the hospital to home was a great feeling, but I was quite scared when he left with the wound because, in fact, from the time he was born, he never had any of this, not even a fall and after he suffered the accident even he was afraid $(R / C 1)$. 
I felt safe to go home with the child, but if I were to do something on his arm I would not be able to do (R/C2).

Then I got worried because I had to be very close, careful, understood? And all mothers have to be worried about this. Because at home I would never have the care you have here $(R / C 4)$.

I felt calm ... I observed how the nurse did and I did the same at home, it was calm. (R/C7).

I do not know, it was all happiness at the time, because the hospital is good, because I know it's for the good of my son, but staying here knowing that at home you have a daughter who depends on you being at home, in the house of others ... I felt happy at that time. (R/C8).

While they were relieved that they were being discharged from the hospital due to the possibility of returning home and resuming their routines, relatives/caregivers expressed fear, concern and a sense of helplessness regarding the need to maintain the care of the child at home. In addition, they perceived themselves in the face of a new and complex experience, which required capacities and resources different from those they possessed.

\section{Difficulties and challenges of relatives/caregivers to care for children with ISI}

Fears and concerns of relatives/caregivers include wetting, causing pain in the child, which conditions them to adopt protective attitudes.

Difficulty that I had is to be picking him up to put in the bathroom to bathe, because he could not stand walking, only... (R/C1).

The shower not to get wet. My concern was this ... And also because he has slept badly. Things [dressings] were taking off, that he has slept badly, and also he pisses a lot, now he can piss every day [laughs], then he would wake up soaked in pee... (R/C4).

Another difficulty mentioned was the financial difficulty to attend periodically in the nursing appointments, which was confirmed in the analysis of the participating families, in which only the conjugate had paid temporary activities.

[...] my difficulty is because I am paying the transportation every day to come, paying to bring me and pick me up here and then leave me in Ipirá. And when he gets here, he's only certified what time he came. Then I lose my working day. [...] (R/C7).
Upon retaking the role of primary caregiver, relatives/ caregivers kept a watchful eye on the child's behavior regarding childhood play, posture during sleep and rest, to avoid injury in the wounds. Therefore, they acted intensifying the care with the child and adopted measures of protection of the injury during the hygienic care, especially the bath, avoiding wetting and contaminating the place. To do so, they kept the injury always covered. Faced with this vigilance and the exhaustive routine of caring for the child, relatives/caregivers compromised their self-care and felt tired and careless with themselves.

By comparing the skills and material resources they had to care for the child with ISI with the professionals and the hospital, they felt unprepared to continue after hospital discharge. Some faced with the impotence they were experiencing and the various difficulties they were facing to care for their children, sought the help of neighbors, friends and other family members, seen as more experienced. However, the care given by lay people caused damages to the physical and emotional health of the child, leaving the family with the feeling of guilt before the temporary or definitive damages evidenced in their child.

\section{Perceptions of the family caregiver about the post-discharge nursing appointments}

In view of the existence of the nursing appointment in the outpatient clinic, in order to continue the specific care for the injuries, and the possibility of access to the medical professional, which the hospital environment provided to the family caregiver, the patient felt embraced, confident and contemplated in meeting the needs of your children. The family caregiver also justifies their adherence to the ambulatory service because they do not find the same material and human resources of care in the primary health care units.

I bring him here. Because in the health center they do not do what they do here. They only clean there, and even then, the bandage of the dressing they put on is not $100 \%$. They just put on it. I think it's important, because here the doctor looks, sees how it is developing, if it is sticking in the right place... (R/C2).

The dressing was to be done here. Only, because of financial conditions, we asked a neighbor to do it and that's what happened ... his finger [got bad]... The recklessness ... Sure he helped a lot, and we also ... It was the situation he was found $[\ldots](R / C 3)$.

To avoid infection ... Yeah ... We do not have practice, but you have... (R/C6).

You have to be watching her always, not to put the dirty things in the wound, especially in the face that is uncovered... Arg! With this agony... We do not eat, we 
do not sleep properly [...] I find it very important [nursing clinic]. It's an important follow-up, because you're seeing there that the nurse is doing the dressing, understand? [...] There are cities that do not have all the material to do. So the child does not get neglected with this care here in the outpatient clinic. $(R / C 10)$.

\section{DISCUSSION}

Children with ISI need post-discharge care to promote their rehabilitation and recovery. Generally, such care is taken care of by the relatives. For this reason, they need to be guided, trained and empowered throughout their hospitalization for home care. ${ }^{10,11}$

The need for rehabilitation of the child with ISI after hospital discharge leads the family to experience a set of feelings that arise when the child's sanity is interrupted and accompany it during the process of restoring skin integrity. Thus, insecurity, concern, fear, impotence and lack of preparation become constant in the lives of these relatives/caregivers when they perceive themselves deprived of preparation for discharge from the nursing team, made available in the hospital during the period of hospitalization. ${ }^{5}$

The feelings experienced by relatives/caregivers are strengthened by insufficient or ineffective guidance during the hospitalization period of the children. In general, health professionals include relatives in the processes of caring as collaborators of simple activities, such as cleaning, calming, positioning or holding the child during procedures, which does not allow the development of skills for more complex care at home, such as dressings. ${ }^{12}$

The professionals, during hospitalization, have difficulty investing time to prepare the caregiver and accept their limitations for the performance of care. ${ }^{12}$ There is a culture of perceiving the family member only as promoter of the child's well-being and intermediary between the family and the team, in an attempt to guarantee their safety and emotional stability, making the period of hospitalization less traumatic. ${ }^{13}$ Thus, it is appropriate for the nursing team to offer the care, since they are part of the daily hospital and depend on skills already acquired by these professionals. ${ }^{13,14}$

This view, however, which is little integrative of those related to the shared care of their children, must be reviewed, since these, in their process of growth and development, are considered as beings in vulnerability and, for this reason, care must be taken also for the acquisition and strengthening of the family's competencies to sustain the care after the end of hospitalization. ${ }^{15}$

In order to do so, the nurse must allow herself to transform her ways of thinking and to focus care on the hospitalized child and her family, in order to, in accordance with the institutional philosophy of care, to empower new caregivers to carry out child care in the post- hospital discharge with safety, responsibility and resolubility. ${ }^{10,12}$ It is indispensable that she be able to assume the posture of facilitator of the process of building autonomy of this family in the promotion of care after hospital discharge, listening to her about her fears, doubts and needs, supporting her in the period of hospitalization, investing in the discharge plan at home, as well as in the guidelines and capacities of these probable relatives/caregivers. ${ }^{5}$

In addition to the feelings that the caring for children with ISI at home entails in the relatives/caregivers, the results showed the pretension that these have to watch over the well-being and the restoration of the skin integrity of the child, attending to their needs, besides reducing in fears of complication of the skin wound. Studies point to the care centered on the preservation of the child's health, in the incessant search for recovery and survival free of physical damage to his health. ${ }^{5,11}$ This affirmation is based on the role that the family, understood as a unit of care, plays before its members. ${ }^{11}$

A priori, the family is seen as responsible for physical, emotional and social well-being, as well as being considered as a socializing institution, creating and encouraging affective bonds, experiencing emotions, developing autonomy and promoting decision-making. ${ }^{10}$ Especially when the child's ability to self-care is compromised, diminished or absent, the family caregiver is a constitutive, interactive element capable of minimizing the biological and psychosocial problems. . $^{6,10,12}$

When empowered to care, the family caregiver performs the procedures as an attitude of care, dedication, attention and good treatment. With this, he reaffirms what literature brings as a fullness of care, when he proposes to this, the dedication to the provision, attention, affection, comfort and other activities that make possible the well-being, the restoration of body and soul and the dignity of the person cared for. ${ }^{5,11}$

Relatives/caregivers face challenges to provide child care after hospital discharge, ranging from the simplest, such as feeding, dressing, sanitizing, wandering, which are essential to the maintenance of life, to the most complex, which require incorporating new knowledge and practices to meet the needs of care, prevent infections and restore health. In addition, there is a need for promotion of safety and emotional support, which are indispensable for the promotion of the child's well-being. ${ }^{16}$

Ensuring homecare care requires adaptations to the ISI and is reflected in a position of overprotection of relatives/ caregivers towards the child at home, to alleviate suffering and avoid recurrence at hospitalization. Overprotection can be a negative factor in the care process, since it contributes to the child's dependence on the family caregiver, does not encourage the expected growth and development in the corresponding age group, and prevents him from living common moments of age, such as playing, going to school and developing some activities to promote self-care. ${ }^{17}$ 
However, it can also be seen as a positive form of care, which results in the protection of the child against possible physical damage to his condition and the risk of aggravation. ${ }^{17}$ This conjecture is strengthened when one understands care from the point of view of those who care for and perceives being cared for, as well as who receives it and the relationship that is built among those involved. Thus, caregiving is reaffirmed when the family caregiver shows an interest in meeting the individual needs of being cared for, in a unique, intrinsic way, aiming to go beyond the significance of the therapeutic appointment, reaching the perspective of maintaining life and ensuring the quality of affective activity inherent in family relationships. ${ }^{18}$

In this perspective, the relatives/caregivers produce a movement of overload and responsibilities for themselves, due to the care to be provided. With this, there is a weakening in their organization in the routines of life and family, due to the care required during the day and at night, to ensure feeding, changing diapers and protection. All these actions, besides causing physical and mental fatigue, also cause the carelessness itself. ${ }^{6}$

Thus, in order for families of children with ISI to face the challenges of home care, the Municipal Health Care Network (Rede de Atenção à Saúde) and the Family Support Network (Rede de Apoio Familiar) should be activated to assist this family caregiver to provide qualified care, access services and appropriate resources, restructure family routines, and mitigate the overload. ${ }^{16}$

When thinking about the articulation with the Family Support Network (Rede de Apoio Familiar), we understand that its success is associated with the awareness of all the members in function of the restoration of the child's hygiene. ${ }^{19}$ With shared care, family members will be empowered to care for and, even if immersed in innumerable difficulties, this fusion becomes the potential of attitudes in the search for the recovery of the child since one is in support of the other.

However, shared caring is not always applicable due to several structural, economic and cultural factors, which places women at greater risk of caring for relatives. This attitude is justified by the reproduction of the rigid definition of roles of the traditional family structure, in which the patriarch is responsible for moral authority, financial provision and protection of the family, and for women to be involved in child development, as well as the function of preserving sexuality, exercise motherhood and dedicate oneself to the home..$^{20,21}$

Coupled with this, the woman still needs time to dedicate herself to the family and share moments with the child as a result of job demands, the non-appropriation of care and commitments regarding child care, plus the imposed cultural approach and stereotypes of gender to which the family is subjected and influenced, which makes motherhood difficult to incorporate into the routine of men. ${ }^{20,21}$

Although overwhelmed, the principal relatives/caregivers recognize the importance of their permanence in the care of the child, since, by strengthening the bond, as well as by acquiring and improving the abilities in caring, they demonstrate a sense of protection and well-being to the child, although they feel weakened by the disorganization of family dynamics. ${ }^{19}$

The primary family caregiver, because of the needs of the child, distances himself from the extra-community work activities and, even using the legal means to justify absenteeism, feels insecure about the possibility of dismissals when living the need to attend the health services more frequently, which can lead to the financial difficulties and implications that also preoccupy and intensify the challenges of child care. ${ }^{22}$

When analyzing the care challenges from the perspective of the Health Care Network, it is necessary to adopt strategies, such as home visits by professionals assigned to these services, creation of groups, among others, in order to promote communication between the levels to identify fragilities and childcare needs, to strengthen the psychological aspect of this family caregiver, and to continue to support and instrumentalize it, so that, while respecting its limits and difficulties, it can restore the child's skin integrity. ${ }^{23}$

However, some barriers in Primary Care compromise the effectiveness of this comprehensive and articulated care. Among these, we mention the absence of materials, the ineffective system of referral and counter-referral, which sometimes condition the family to be a reproducer of the guidelines of hospital professionals and does not promote early uptake and follow-up by the nurse, the child and their relative caregiver.

The absence of specialists is also observed; difficulties with transportation for home visits by professionals; bureaucratization, which does not optimize nursing appointments; and the performance of procedures, such as dressings, which are delegated by the nurse to less qualified professionals, which may lead to a breakdown of the technique and the use of inappropriate treatments for the continuity of hospital care. These are aspects that may delay the restoration of the child's skin integrity and reveal a fragmentation in the comprehensiveness of the systemic care that the child requires. ${ }^{23}$

In this context, nursing appointments, in the post-discharge environment of the child, can be seen as a proposal that allows access to health services, strengthens the abilities of relatives/ caregivers, addresses health education practices directed at subjects of interest, in order to overcome their difficulties and negative feelings, in addition to promoting the restoration of the child's skin integrity. ${ }^{23}$

As these objectives are achieved, the strengthening of the bond between those involved is achieved and the autonomy, the promotion of safety, independence and accountability of relatives/caregivers regarding practices regarding the child's needs are rescued. In the relationship with the nursing professional, they feel supported to offer better health conditions, life and minimization of possible problems, providing them with more confidence to expose their doubts and (lack of) safety in the performance of care. ${ }^{24}$ 
In order to do so, it is necessary to take care of the host as a fundamental element, which fosters a space for listening to the child's health needs and promotes a humane and resolute service. Nursing appointments should be considered as a dialogical space in which it is possible to discuss the complexity of the care required by children with ISI, the need to (re) elaborate practices for care, accepting approximations of the understanding of the decisions made and strategies adopted. This implies the sharing of knowledge that culminates in the assumption of rational ways of promoting health, taking into account the interrelations between those involved and the contexts in which they are inserted. ${ }^{25}$

\section{CONCLUSIONS AND IMPLICATIONS FOR PRACTICE}

This study evidenced that the maintenance of care for children with impaired skin integrity in hospital post-discharge requires the application of measures of protection of the skin wounds, the constant vigilance of the child in the prevention of local traumas and infections and the search for support in the health units to obtain material resources and guidelines for care.

Thus, during hospitalization, there is a need to strengthen family-centered care, especially nursing, by supporting and providing the necessary support so that this moment becomes less painful and traumatic for the family and their child, as well as guiding and training this family caregiver for the continuity of care, since we have opted for early hospital discharge, but not with complete health restoration.

As a result of this research, from the action research method, a nursing clinic was set up to attend the child with ISI after hospital discharge, in order to enhance autonomy of the family caregiver and to support the acquisition of skills and competencies to confront positively the processes of restoring children's health.

Among the limitations of this study is the reduced number of participants and the offer of appointment only once a week, since its expansion could give rise to different challenges and perceptions about child care.

\section{REFERENCES}

1. Rolim JA, Vasconcelos JMB, Caliri MHL, Santos IBC. Prevenção e tratamento de úlceras por pressão no cotidiano de enfermeiros intensivistas. Rev Rene [Internet]. 2013 Jul/Nov; [cited 2017 Jul 1] 14(1):148-57. Available from: http://www.periodicos.ufc.br/rene/article/ view/3346

2. Silva AS, Valácio RA, Botelholl FC, Amaral CFS. Reasons for discharge delays in teaching hospitals. Rev Saúde Pública [Internet]. 2014 Apr [cited 2017 Jul 1]; 48(2):314-21. Available from: https://www.ncbi.nlm. nih.gov/pmc/articles/PMC4206133/

3. Delatorre PG, Sá SPC, Valente GSC, Silvino ZR. Planning for hospital discharge as a strategy for nursing care: integrative review. Rev Enferm UFPE [Internet]. 2013 Dec; [cited 2017 Jul 1]; 7(no.esp):7151-9. Available form: https://periodicos.ufpe.br/revistas/revistaenfermagem/ article/view/12387/15148
4. Othman D. Negative pressure wound therapy literature review of efficacy cost effectiveness, and impact on patients' quality of life in chronic wound management and its implementation in the United Kingdom. Plast Surg Int [Internet]. 2012 Dec/Apr; [cited 2017 Jul 1]; 2012;2012:374398. Available from: https://www.hindawi.com/journals/psi/2012/374398/

5. Pinto JP, Mandetta MA, Ribeiro CA. A família vivenciando o processo de recuperação da criança pós-alta hospitalar. Rev Bras Enferm [Internet]. 2015 Aug; [cited 2018 Jul/Aug 10]; 68(4):594-602. Available from: http://www.scielo.br/scielo.php?script=sci_arttext\&pid=S0034$71672015000400594 \&$ Ing $=$ en\&nrm=iso

6. Barreto MS, Arruda GO, Garcia-Vivar C, Marcon SS. Cuidado centrado na família em unidades emergenciais: percepção de enfermeiros e médicos brasileiros. Esc Anna Nery Rev Enferm [Internet]. 2017 Apr [cited 2017 Jul 2]; 21(2):e20170042. Available from: http://www.scielo. br/pdf/ean/v21n2/1414-8145-ean-21-02-e20170042.pdf

7. Bardin L. Análise de Conteúdo. Tradução de Luís Antero Reto e Augusto Pinheiro. São Paulo: Edições 70; 2011. p. 95-103.

8. Chesnay M. Nursing research using participatory action research: qualitative designs and methods in nursing [Internet]. New York: Springe Publishing;2014 [cited 2017 Jul 3]. Available from: https://books.google. com.br/books?id=_w6gBQAAQBAJ\&pg=PA21\&lpg=PA21\&dq=NursiN g++research++usi $\mathrm{Ng}++$ ParticiPatory++actioN+research+refer\%C3\%A Ancia\&source $=$ bl\&ots $=$ =Co3WxxhVe\&sig $=X 2 x$ UtIPVMQ8ezH4h0nTzD 3SOHOg\&hl=pt-BR\&sa=X\&ved=0ahUKEwjkxd_1reTUAhWDhZAKH XSnCxwQ6AEIQDAD\#v=onepage\&q=NursiNg\%20\%20research\%20 \%20usiNg\%20\%20ParticiPatory\%20\%20actioN\%20research\%20 refer\%C3\%AAncia\&f=false

9. Tanajura LLC, Bezerra AAC. Pesquisa-ação sob a ótica de René Barbier e Michel Thiollent: aproximações e especificidades metodológicas. Rev Eletr Pesqueduc [Internet]. 2015 Jan/Jun; [cited 2017 Jul 8]; 7(13):10-23. Available from: periodicos.unisantos.br/index.php/pesquiseduca/article/ download/408/pdf

10. Silveira A, Neves ET, Paula CC. Family care of children with special healthcare needs: a process of (super) natural care and (over) protection. Text Context Enferm [Internet]. 2013 Oct/Dec; [cited 2017 Jul 8];22(4):1106-14. Available from: http://www.scielo.br/pdf/tce/v22n4/ en_29.pdf

11. Amaral LFP, Calegari T. Humanização da assistência de enfermagem à família na unidade de terapia intensiva pediátrica. Cogitare Enferm [Internet]. $2016 \mathrm{Jul} / \mathrm{Sep}$; [cited $2017 \mathrm{Jul}$ 9]; 21(3):1-9. Available from: http://revistas.ufpr.br/cogitare/article/view/44519/pdf15

12. Corrêa AR, Andrade AC, Manzo BF, Couto DL, Duarte ED. As práticas do cuidado centrado na família na perspectiva do enfermeiro da Unidade Neonatal. Esc Anna Nery Rev Enferm [Internet]. 2015 Oct/Dec; [cited 2017 July 9]; 19(4):629-34. Available from: http://www.scielo.br/pdf/ean/ v19n4/1414-8145-ean-19-04-0629.pdf

13. Marques CDC, Lima MF, Malaquias TSM, Waidman MAP, Higarashi $\mathrm{IH}$. O cuidador familiar da criança hospitalizada na visão da equipe de enfermagem. Ciênc Cuid Saúde [Internet]. 2014 Jul/Sep; [cited 2017 Jul 9]; 13(3):541-8. Available from: http://www.periodicos.uem.br/ojs/ index.php/CiencCuidSaude/article/viewFile/22133/pdf_227

14. Melo EMOP, Ferreira PL, Lima RAG, Mello DF. Envolvimento dos pais nos cuidados de saúde de crianças hospitalizadas. Rev Lat Am Enferm [Internet]. 2014 May/Jun; [cited 2017 Jul 9]; 22(3):432-9. Available from: http://www.scielo.br/pdf/rlae/v22n3/pt_0104-1169-rlae-22-03-00432. pdf

15. Salvador MS, Gomes GC, Oliveira PK, Gomes VLO, Busanello J, Xavier DM. Strategies of families in the care of children with chronic diseases. Text Context Enferm [Internet]. $2015 \mathrm{Jul} / \mathrm{Sep}$; [cited $2017 \mathrm{Ju}$ 9];24(3):662-9. Available from: http://www.scielo.br/pdf/tce/v24n3/01040707-tce-24-03-00662.pdf

16. Araújo YB, Reichert APS, Vasconcelos MGL, Collet N. Fragilidade da rede social de famílias de crianças com doença crônica. Rev Bras Enferm [Internet]. 2013 Oct; [cited 2018 Aug 2]; 66(5):675-81. Available from: http://www.scielo.br/scielo.php?script=sci_arttext\&pid $=$ S0034-71672013000500006 
17. Neves ET, Silveira A. Challenges for family caregivers of children with special health care needs: contributions of nursing. J Nurs UFPE On Line [Internet]. 2013 May; [cited 2017 Jul 9]; 7(5):1458-62. Available from: https://periodicos.ufpe.br/revistas/revistaenfermagem/article/ view/11633

18. Nishimoto CLJ, Duarte ED. A organização familiar para o cuidado à criança em condição crônica, egressa da unidade de terapia intensiva neonatal. Texto Contexto Enferm [Internet]. 2014 Apr/Jun; [cited 2017 Jul 9];23(2):318-27. Available from: http://www.scielo.br/pdf/tce/v23n2/ pt_0104-0707-tce-23-02-00318.pdf

19. Colliére MF. Promover a vida: da prática das mulheres de virtude aos cuidados de enfermagem. $5^{a}$ ed. Lisboa (PT): Lidel Edições Técnicas; 1999.

20. Silva AV, Dauber L. O papel do pai na sociedade contemporânea. Interbio [Internet]. 2013; [cited 2017 Jul 9]; 7(2):57-66. Available from: http://www.unigran.br/interbio/paginas/ed_anteriores/vol7_num2/ arquivos/artigo7.pdf

21. Carrilo $S$, Bermúdez M, Suárez L, Gutiérrez MC, Delgado X. Father's Perceptions of their Role and Involvement in the Family: A Qualitative Study in a Colombian Sample. Rev Costarric Psic [Internet]. $2016 \mathrm{Jul} /$ Dec; [cited 2017 Jul 9]; 35(2):37-54. Available from: http://www.scielo. sa.cr/scielo.php?script=sci_arttext\&pid=S1659-29132016000200037
22. Passos SSS, Pereira A, Nitschke RG. Cotidiano do familiar acompanhante durante a hospitalização de um membro da família. Acta Paul Enferm [Internet]. 2015 Jun/Nov; [cited 2017 Jul 10]; 28(6):53945. Available from: http://www.scielo.br/scielo.php?pid=S010321002015000600539\&script=sci_abstract\&tlng=pt

23. Aires LCP, Santos EKA, Costa R, Borck M, Custódio ZAO. Baby follow-up in primary care: interface with the third stage of the kangaroo method. Rev Gaúcha Enferm [Internet]. 2015 Jun/Oct; [cited 2017 July 10]; 36(no.esp):224-32. Available from: http://www.scielo.br/scielo. php?script=sci_arttext\&pid=S1983-14472015000500224\&lng=en\&n $\mathrm{rm}=\mathrm{iso} \&$ tlng=en

24. Silva KR, Figueiroa AG, Mendes CCM, Cruz JCL, Freitas RL. Doença do refluxo gastroesofágico: principais orientações proferidas pelo Enfermeiro ao cuidador familiar de crianças entre 0 e 2 anos de vida. NBC - Periódico Cient Núcleo Biociênc [Internet]. 2015 Aug; [cited 2017 Jul 10]; 5(9):11-20. Available from: https://www.metodista.br/revistas/ revistas-izabela/index.php/bio/article/view/888

25. Estevam DCM, Silva JDD. Visão das mães em relação ao cuidado com o recém-nascido após a alta da uti neonatal. Rev Saúde Pesq [Internet]. 2016 Jan/Apr; [cited 2017 Jul 13]; 9(1):15-24. Available from: periodicos.unicesumar.edu.br/index.php/saudpesq/article/ download/4161/2745

a Article elaborated from the dissertation "Nursing Consultation for Children with Loss of Cutaneous Integrity Post-Alta from Hospital", presented to the Professional Master's Degree in Nursing at the State University of Feira de Santana/UEFS and defended on August 28, 2017. 